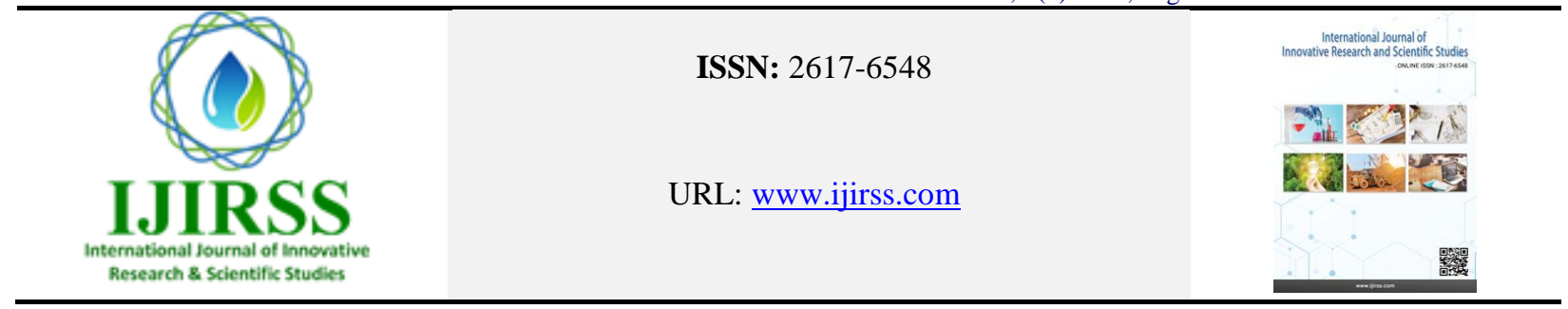

\title{
Barriers to Learning Dari Literature among Non-Persian Language Students of the Dari Department of Jawzjan University
}

\author{
Hussain Radfar \\ Department of Dari Literature, Faculty of Education, Jawzjan University, Jawz.jan, Afghanistan \\ (Email: hossain.radfar@yahoo.com )
}

\begin{abstract}
This paper, which is written under the title "Barriers to learning Dari literature among non-Persian language students of the Dari department of Jawzjan University", contains challenges and solutions through which the problem of learning Dari literature among the students of this department can be identified and will be solved by the application of the solutions presented in this paper. The main purpose of this study is to identify the general and minor barriers that non-Persian language students of the Dari Department of Jawzjan University struggle with to learn better. Therefore, this research is very important, because so far no research has been done in this field. The research method applied in this research is a descriptive-survey method. The population of this study was 67 students, and the sample size $(n=57)$ was selected using Cochran's formula. SPSS software was used to analyze the data. Findings of the present study confirm the hypotheses such as the poor academic foundation of students, the unfamiliarity of teachers and students with modern teaching methods, lack of educational facilities, lack of motivation by families and teachers, and insufficient ability to the Dari language.
\end{abstract}

Keywords: Learning Barriers, Dari Language, Second Language, Learning Methods.

DOI: 10.53894 /ijirss.v4i1.50

Funding: This study received no specific financial support.

History: Received: 27 September 2020/Revised: 17 December 2020/Accepted: 9 January 2021/Published: 8 February 2021

Licensed: This work is licensed under a Creative Commons Attribution 4.0 License (cc) Er

Acknowledgement: All authors contributed to the conception and design of the study.

Competing Interests: The author declares that there are no conflicts of interests regarding the publication of this paper.

Transparency: The author confirm that the manuscript is an honest, accurate, and transparent account of the study was reported; that no vital features of the study have been omitted; and that any discrepancies from the study as planned have been explained.

Ethical: This study follows all ethical practices during writing. 


\title{
شناسايى موانع يادكيرى ادبيات درى در دانشجويان غير فارسى زبان ديبارتمنت درى دانشعاه جوزجان
}

\author{
حسين رادفر \\ دبيارتمنت ادبيات درى، دانشكدة تعليم و تربيه، دانشعاه جوزجان، جوزجان، افغانستان \\ خلاصه
}

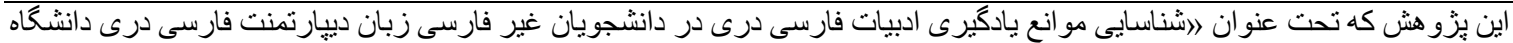

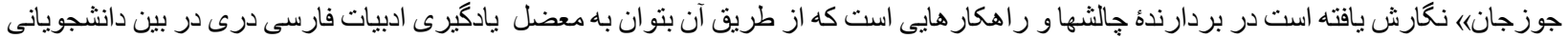

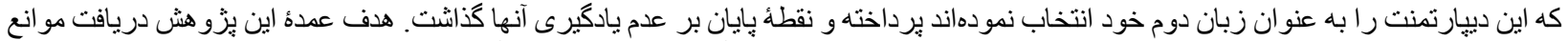

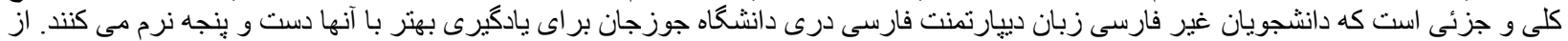

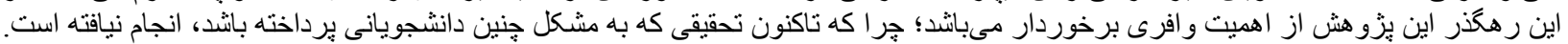

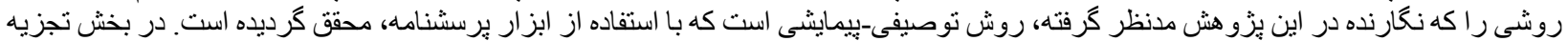

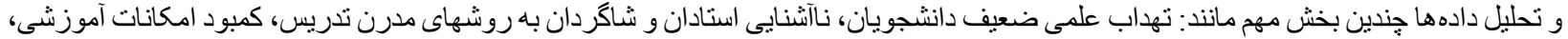

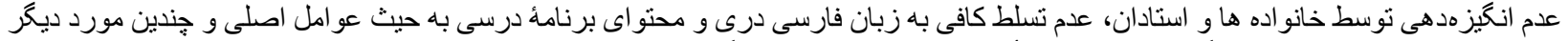

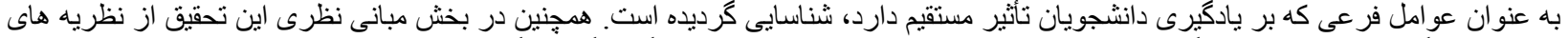

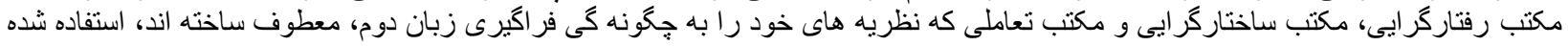

وازه هاى كليدى: موانع يادكيرى، زبان فارسى درى، زبان دوم، شيوه هاى آموزش

1 1

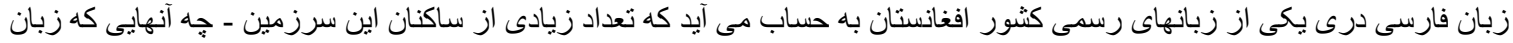

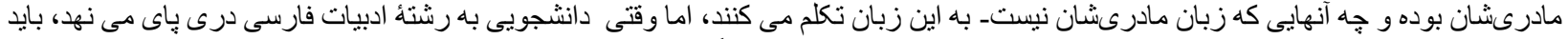

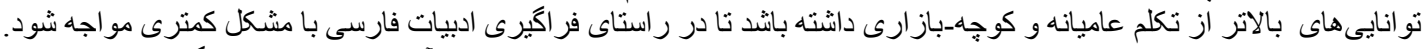

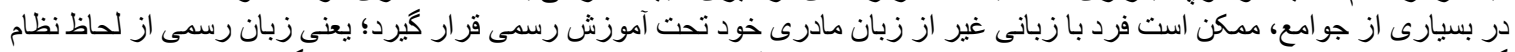

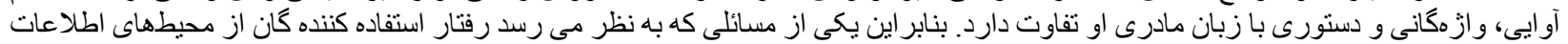

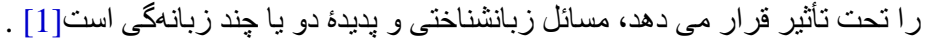

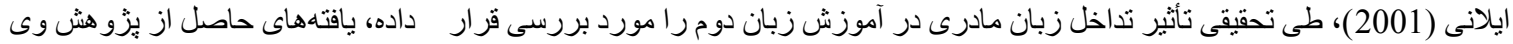

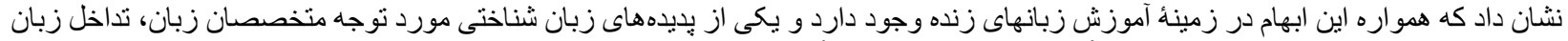

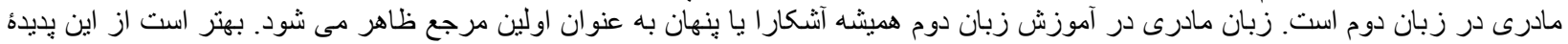

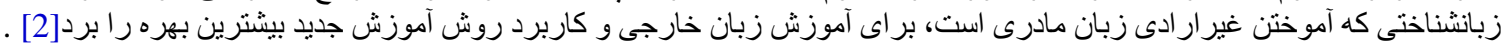

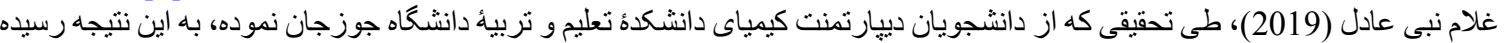

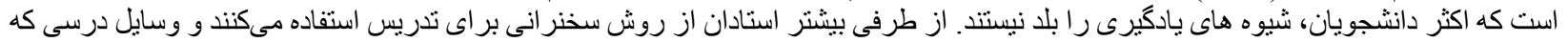

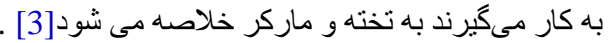

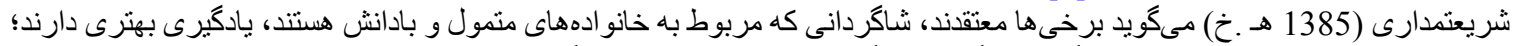

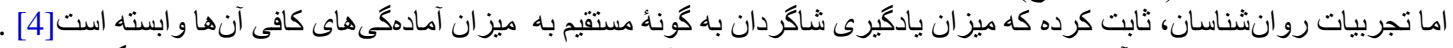

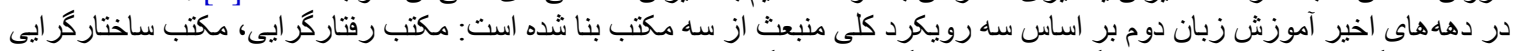

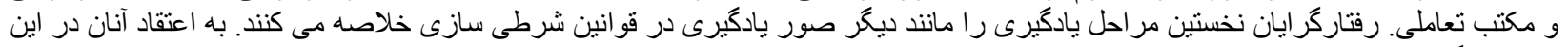

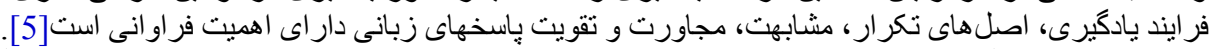

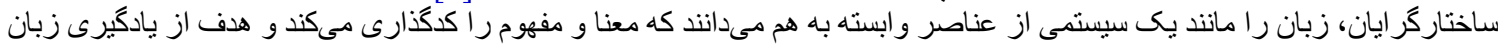

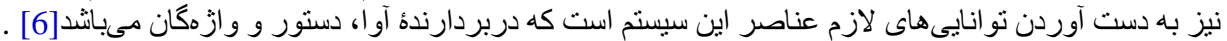

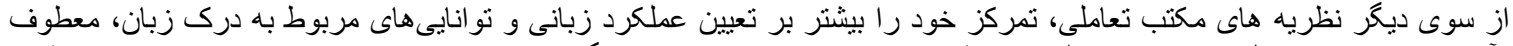

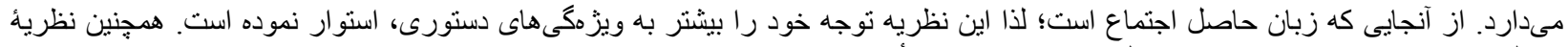

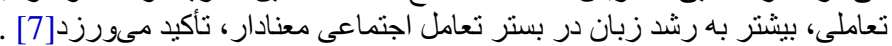

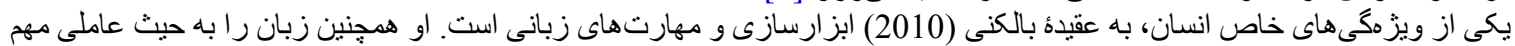

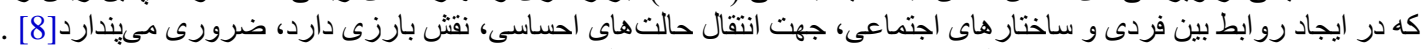

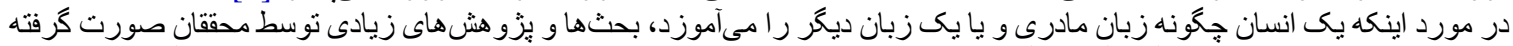

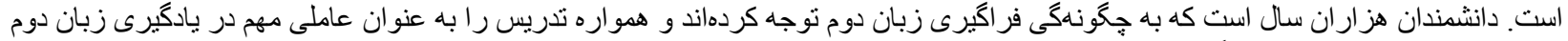

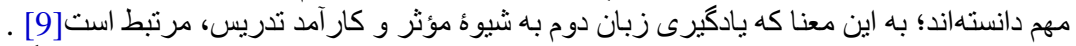

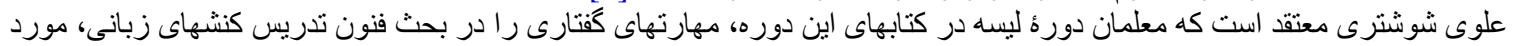

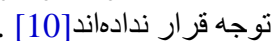

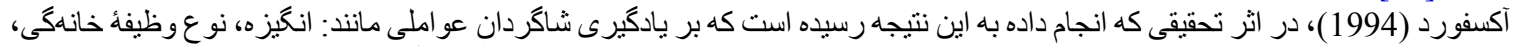

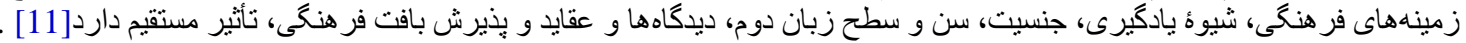


1- عدم تمكلم بـه زبان درى در خانو اده و اجتماع، باعث كاهش يادكيرى ادبيات فارسى درى در دانشجويان كرديده است.

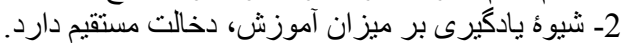

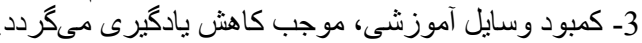

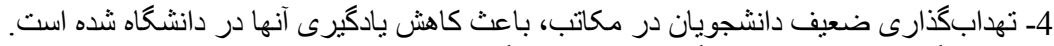

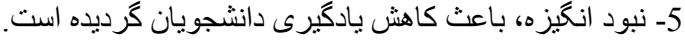

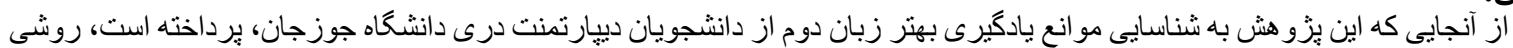

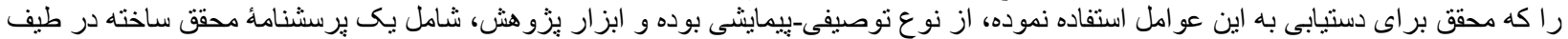

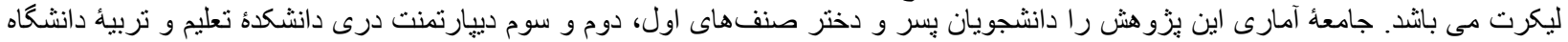

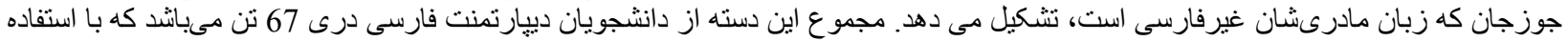

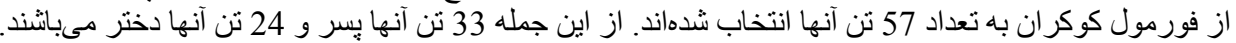

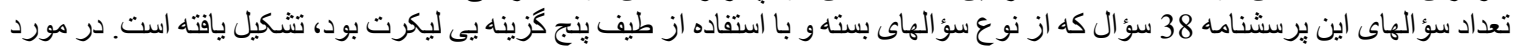

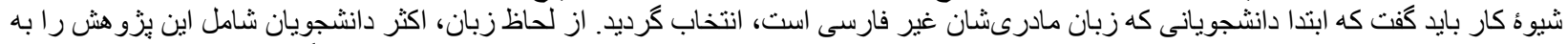

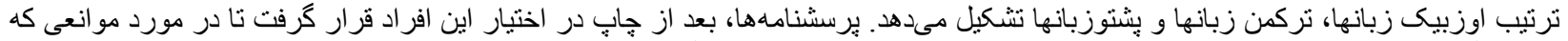

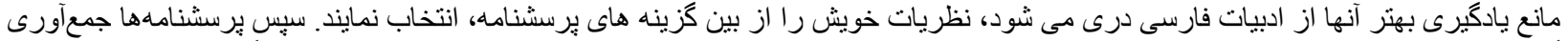

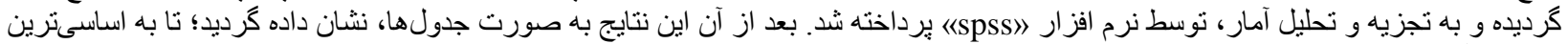

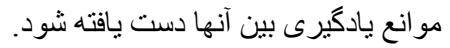

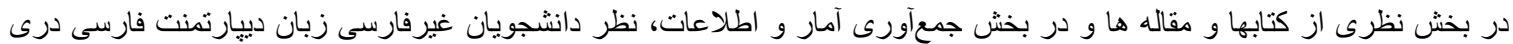

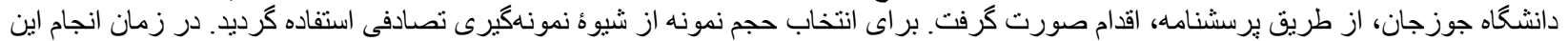

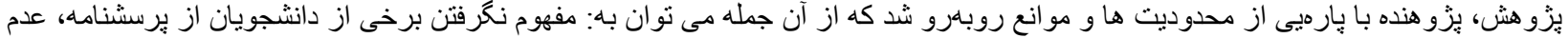

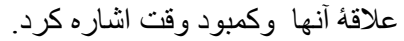
يافتههاى تحقيق:

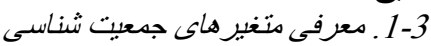

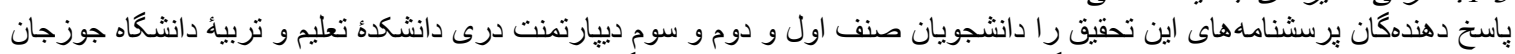

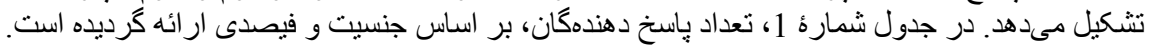

جدول شمارة 1: فراو انى شركت كنندهان برسشنامه بر اساس جنسيت و فيصدى آن

\begin{tabular}{|c|c|c|c|c|c|}
\hline \multicolumn{6}{|c|}{ جنسيت } \\
\hline & & Frequency & Percent & Valid Percent & Cumulative Percent \\
\hline \multirow{3}{*}{ Valid } & مرد & 33 & 57.9 & 57.9 & 57.9 \\
\hline & زن & 24 & 42.1 & 42.1 & 100.0 \\
\hline & مجموع & 57 & 100.0 & 100.0 & \\
\hline
\end{tabular}

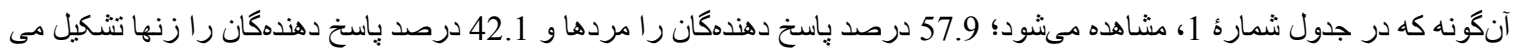
دهند كه به ترتيب تعداد آنها 33 و 24 نن مي بانثد.

جدول شمار 2: 2: فر اوانى شركت كنندكان برسشنامه بر اساس قوميت و فيصدى آن

\begin{tabular}{|c|c|c|c|c|c|}
\hline \multicolumn{6}{|c|}{ قوميت } \\
\hline & & Frequency & Percent & Valid Percent & Cumulative Percent \\
\hline \multirow{5}{*}{ Valid } & اوزبيك & 37 & 64.9 & 64.9 & 64.9 \\
\hline & تركمن & 12 & 21.1 & 21.1 & 86.0 \\
\hline & يشتُون & 6 & 10.5 & 10.5 & 96.5 \\
\hline & اقوام ديكر & 2 & 3.5 & 3.5 & 100.0 \\
\hline & مجموع & 57 & 100.0 & 100.0 & \\
\hline
\end{tabular}

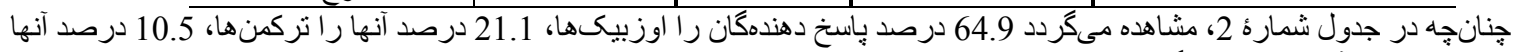

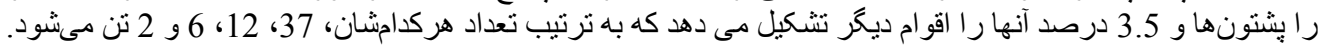

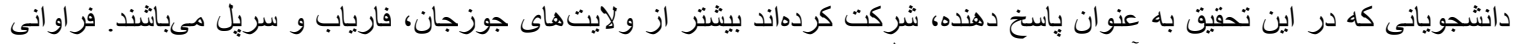

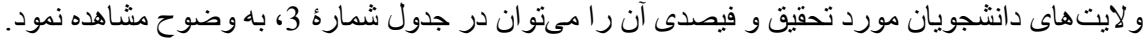




\begin{tabular}{|c|c|c|c|c|c|}
\hline \multicolumn{6}{|c|}{ ولايت } \\
\hline \multirow{6}{*}{ Valid } & & Frequency & Percent & Valid Percent & Cumulative Percent \\
\hline & جوزجان & 33 & 57.9 & 57.9 & 57.9 \\
\hline & فارياب & 18 & 31.6 & 31.6 & 89.5 \\
\hline & سريل & 5 & 8.8 & 8.8 & 98.2 \\
\hline & ساير و لايتها & 1 & 1.8 & 1.8 & 100.0 \\
\hline & مجموع & 57 & 100.0 & 100.0 & \\
\hline
\end{tabular}

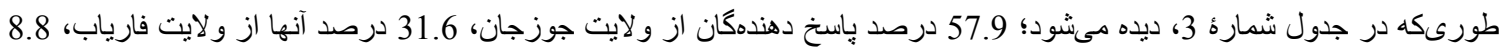

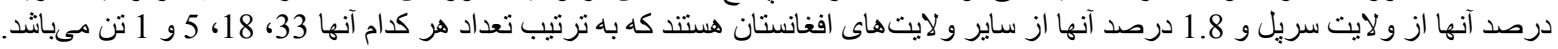

آزمون فزضميهها:

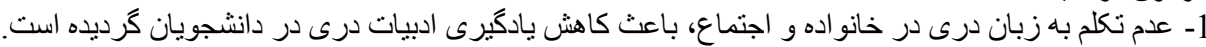

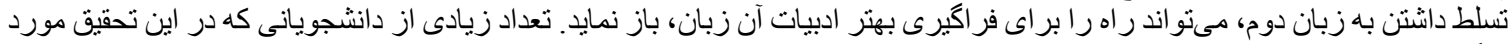

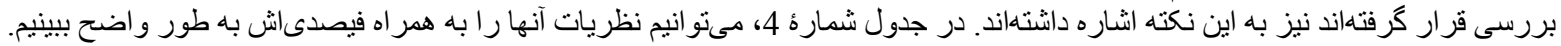

جدول شمارة 4: فراو انى نقش عدم تكلم به زبان درى در خانو اده و جامعه بر كاهش بادئ بادكيرى دانشجويان

\begin{tabular}{|c|c|c|c|c|c|}
\hline \multicolumn{6}{|c|}{ تأثيّر عدم تعلم به زبان درى در جامعه و كاهش يادكيرى دانثجويان } \\
\hline & & Frequency & Percent & Valid Percent & Cumulative Percent \\
\hline \multirow[t]{6}{*}{ Valid } & كاملا مو افق & 26 & 45.6 & 45.6 & 45.6 \\
\hline & 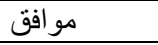 & 15 & 26.3 & 26.3 & 71.9 \\
\hline & بى نظر & 9 & 15.8 & 15.8 & 87.7 \\
\hline & 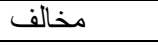 & 4 & 7.0 & 7.0 & 94.7 \\
\hline & كاملا مخالف & 3 & 5.3 & 5.3 & 100.0 \\
\hline & مجموع & 57 & 100.0 & 100.0 & \\
\hline
\end{tabular}

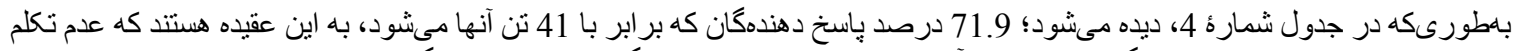

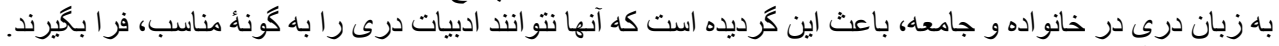

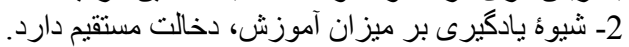

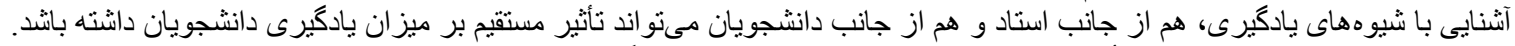
جدول شمارة 5، روش باى نادرست استادان و تأثثير آن را به همر اه فيصدى اش بان بر كاهش يادكيرى دانثجويان مشاهده مى نماييد. جدول شمارة 5: فر او انى روشهاى نادرست تدريس استادان بر كاهش يادكيرى دانشجويان و فيصدى آن

\begin{tabular}{|c|c|c|c|c|c|}
\hline \multicolumn{6}{|c|}{ روش هاى نادرست تدريس استادان } \\
\hline \multirow{2}{*}{$\overline{\text { Valid }}$} & & Frequency & Percen & Valid Percent & Cumulative Percent \\
\hline & كاملا مو افق & 32 & 56.1 & 56.1 & 56.1 \\
\hline & 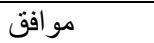 & 11 & 19.3 & 19.3 & 75.4 \\
\hline & بى نظر & 6 & 10.5 & 10.5 & 86.0 \\
\hline & مخالف & 5 & 8.8 & 8.8 & 94.7 \\
\hline & كاملا مخالف & 3 & 5.3 & 5.3 & 100.0 \\
\hline & مجموع & 57 & 100.0 & 100.0 & \\
\hline
\end{tabular}

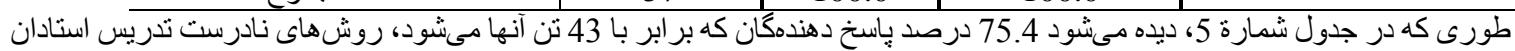

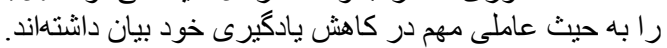

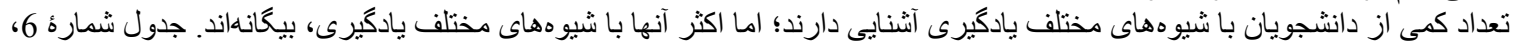

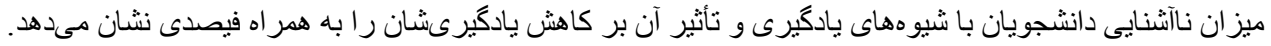

جدول شمارة 6: فراو انى نآشنايى دانشجويان با شيوه هاى مختلف يادكيرى و كاهش آموزش بانش آنها

\begin{tabular}{|c|c|c|c|c|c|}
\hline \multicolumn{6}{|c|}{ تأثير ناآثنايى دانشجويان با شيوه هاى يادكيرى بر ميزان آموزش آنها } \\
\hline & & Frequency & Percent & Valid Percent & Cumulative Percent \\
\hline \multirow[t]{4}{*}{ Valid } & كاملا مو افق & 17 & 29.8 & 29.8 & 29.8 \\
\hline & موافق & 17 & 29.8 & 29.8 & 59.6 \\
\hline & بى نظر & 8 & 14.0 & 14.0 & 73.7 \\
\hline & مخالف & 10 & 17.5 & 17.5 & 91.2 \\
\hline
\end{tabular}




\begin{tabular}{l|c|c|c|c}
\hline كاملا مخالف & 5 & 8.8 & 8.8 & 100.0 \\
\hline مجمو & 57 & 100.0 & 100.0 & \\
\hline
\end{tabular}

به طورى كه در جدول شمارة 6، ديده مى شود؛؛

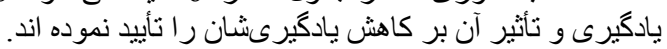

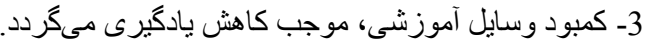

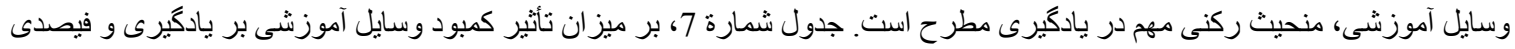
نظر دانشجويان در اين زمينه اشاره مى نمايد.

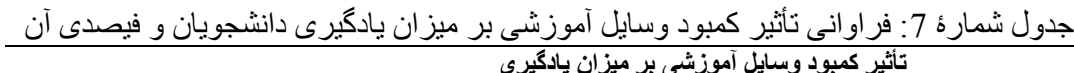

\begin{tabular}{|c|c|c|c|c|c|}
\hline \multicolumn{6}{|c|}{ تأثيّر كمبود وسايل آموزشى بر ميزان يادكيرى } \\
\hline \multirow{6}{*}{ Valid } & & Frequency & Percent & Valid Percent & Cumulative Percent \\
\hline & كاملا مو افق & 33 & 57.9 & 57.9 & 57.9 \\
\hline & مو افق & 17 & 29.8 & 29.8 & 87.7 \\
\hline & بى نظر & 4 & 7.0 & 7.0 & 94.7 \\
\hline & 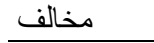 & 3 & 5.3 & 5.3 & 100.0 \\
\hline & مجموع & 57 & 100.0 & 100.0 & \\
\hline
\end{tabular}

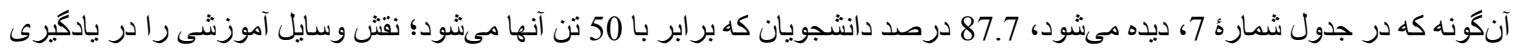

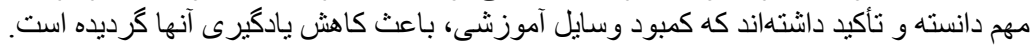
4- تهدابكذارى ضعيف دانشجويان در مكاتب، باعث كاهش بادثئ باديرى آنها در دانشكاه شده است.

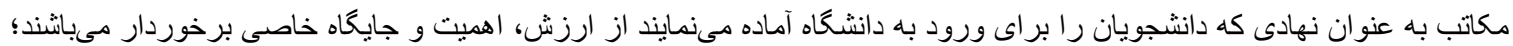

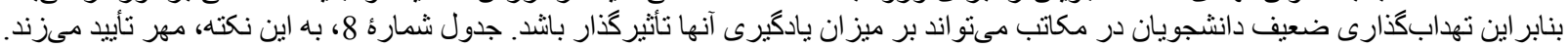

\begin{tabular}{|c|c|c|c|c|c|}
\hline \multicolumn{6}{|c|}{ 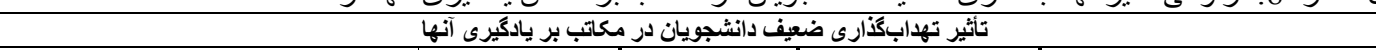 } \\
\hline & & Frequency & Percent & Valid Percent & Cumulative Percent \\
\hline \multirow[t]{6}{*}{ Valid } & كاملا مو افق & 35 & 61.4 & 61.4 & 61.4 \\
\hline & مو افق & 11 & 19.3 & 19.3 & 80.7 \\
\hline & 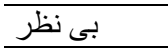 & 4 & 7.0 & 7.0 & 87.7 \\
\hline & مخالف & 5 & 8.8 & 8.8 & 96.5 \\
\hline & كاملا مخالف & 2 & 3.5 & 3.5 & 100.0 \\
\hline & مجموع & 57 & 100.0 & 100.0 & \\
\hline
\end{tabular}

آنكونه كه در جدول شمارؤ 8، ديده مىشود؛

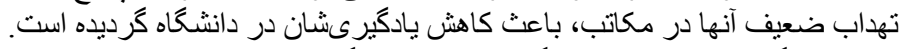

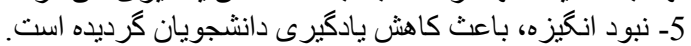

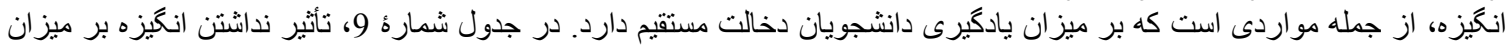

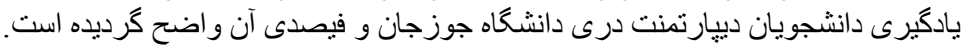
جدول شمارة 9: فراو انى عدم انكيز ددهى خانو اده و استادان به دانشجويان و كاهش يادكيرى آنها

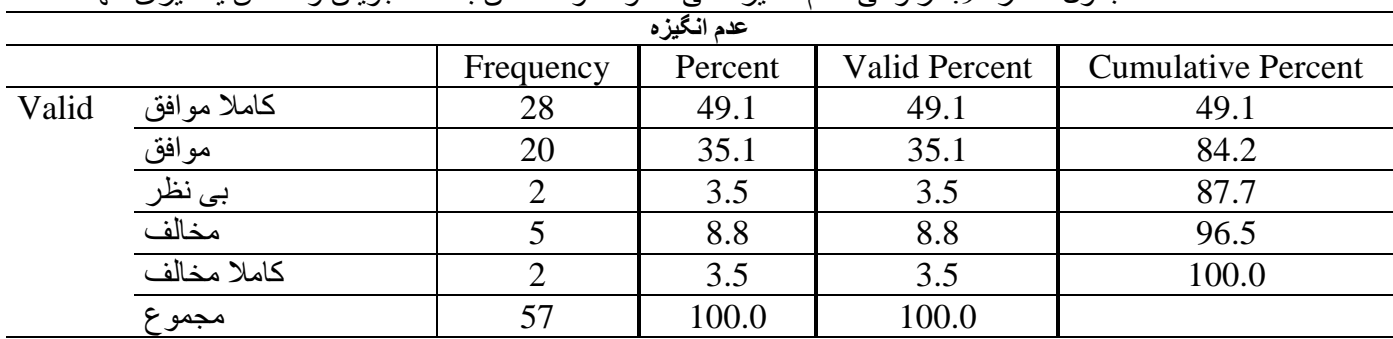

آنكونه كه در جدول شمارة 9، مشاهده مىشود؛؛ 84.2 درصد باسخخ دهندمكان كه بر ابر با 48 نن آنها مىشود، نداشتن انكيزه را به حيث

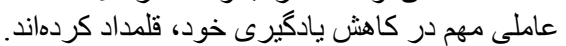

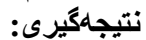

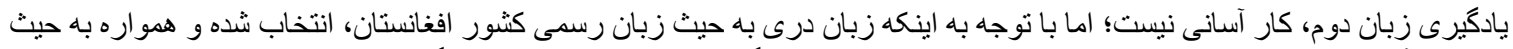

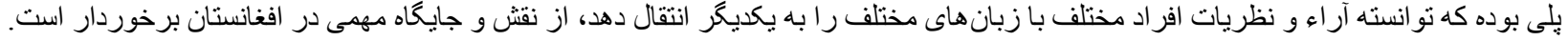




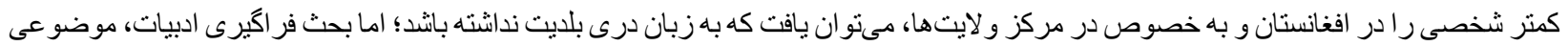

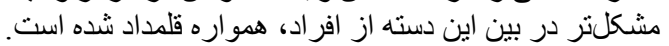

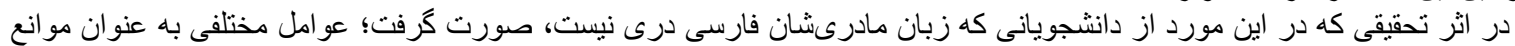

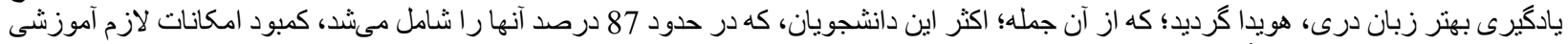

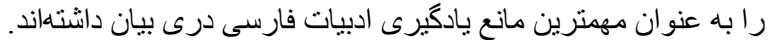

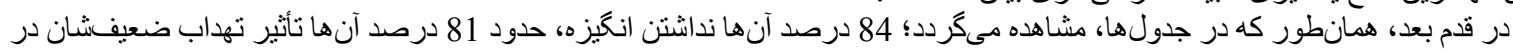

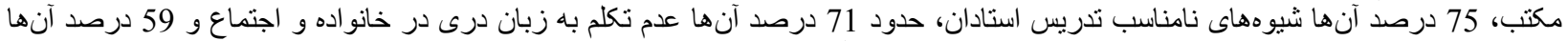

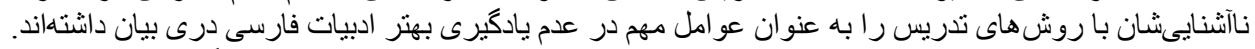

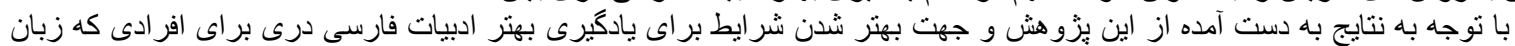

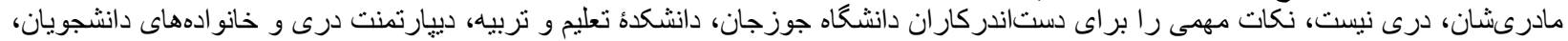

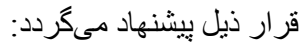

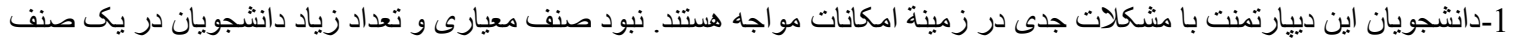

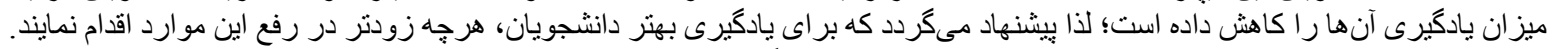

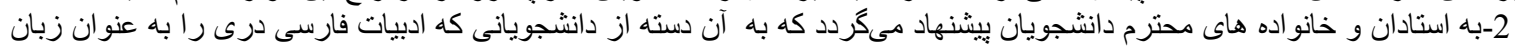

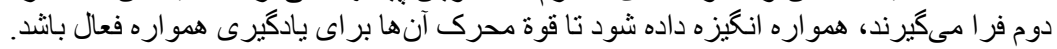

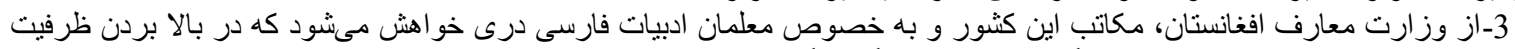

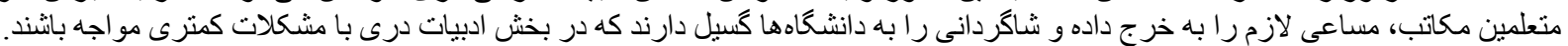

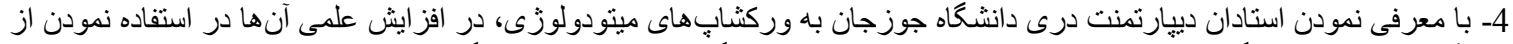

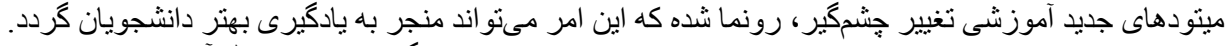

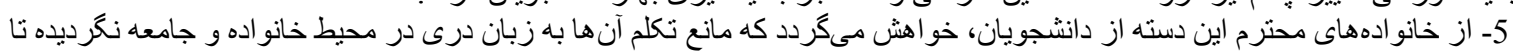

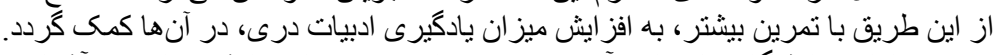

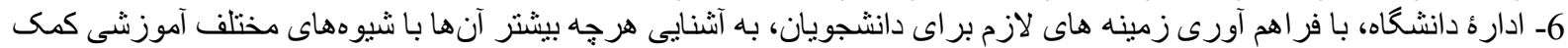

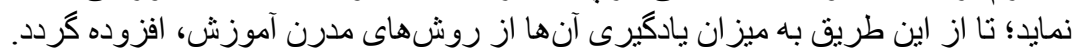

\section{References}

[1] Mokhtari, "Mollai linguistic barriers to bilingualism in the information behavior of Turkmen-Persian bilingual students," Library Research and Academic Information, vol. 47, pp. 85-96, 2013.

[2] A. T. Behroozi and Y. Alipour, "Pathology of english language curriculum from the perspective of high school teachers and students," Quarterly Journal of New Approach in Educational Management, Marvdasht, University Press, vol. 2, pp. 125-142, 2014.

[3] G. N. Adil, M. H. Neda, and Z. Dahi, "Finding different learning methods of chemistry department students, education faculty of Jawzjan University," International Journal of Innovative Research and Scientific Studies, vol. 2, pp. 1-9, 2019.

[4] Shariatmadari, Educational psychology, 19th ed. Tehran: Amirkabir Publications, 2006.

[5] S. Police and C. Gholami, "Identifying and prioritizing factors related to English language teaching in schools," Quarterly Journal of Educational Innovations, vol. 46, pp. 97-122, 2013.

[6] H. D. Brown, Teaching by principle an interactive approach to language pedagogy, 2nd ed. White Plains: NY, Person Education, 2001.

[7] M. H. Long, "Native speaker/non-native speaker conversation and the negotiation of comprehensible input1," Applied Linguistics, vol. 4, pp. 126-141, 1983.Available at: https://doi.org/10.1093/applin/4.2.126.

[8] M. Balconi, Neuropsychology of communication. Milan: Springer, 2010.

[9] F. Newmeyer and S. H. Weinberger, The ontogenesis of second language learning research, generative linguistics. London: Routledge, 1996.

[10] A. S. Shoshtari, "A multi-variety causal of motivation in second/foreign language learning," PhD Thesis, Shiraz University, Iran, 2004.

[11] R. Oxford, "Langauge learning starteges: An update," University of Alabma, 1994. 